\title{
CORAK TAFSIR MUHAMMADIYAH
}

\author{
Rohmansyah \\ Universitas Muhammadiyah Yogyakarta, Indonesia \\ rohmansyah@umy.ac.id
}

\begin{abstract}
This research aims to know the pattern of interpretation of Muhammadiyah. The pattern of the interpretation of these two works dedicated to the interpretation of the institutions laid down in the Assembly and its special Tajdid Tarjih discusses the religious field, namely the Tafsir al-Qoer'an and Thematic Tafseer of Religious Relations. Research methods used are literature library (library research) by using a descriptive approach-analytical methods. Results of the study showed, the pattern of interpretation of Muhammadiyah is tafsîr bi al-ra'yi who was known among the Muhammadiyah as tafsir which are ijtihadi (thought), resulting in the development of not only its interpretation using solely the opinions of the scholars, but also menginterkoneksikan and correlate with other verses, Hadith of the Prophet, the opinions of friends and tab 'in. Two methods are used in delivering its interpretation is the method maud $\hat{u}$ ' $i$ and tahlîli. The interpretation of the Muhammadiyah in order that the Qur'an really be sâlihun li kulli zamânin wa makânin (according to all the time and place), so his teachings can be understood and applied in real life.
\end{abstract}

Keywords: Interpretation, Methods, Tafsir, Muhammadiyah, Pattern

\begin{abstract}
Abstrak
Penelitian ini bertujuan untuk mengetahui Corak Tafsir Muhammadiyah. Corak Tafsir tersebut ditujukan kepada dua karya tafsir yang digagas lembaga Majelis Tarjih dan Tajdid yang khusus membahas bidang keagamaan, yaitu Tafsir al-Qoer'an dan Tafsir Tematik tentang Hubungan Antar Umat Beragama. Metode penelitian yang digunakan adalah literatur kepustakaan (library research) dengan menggunakan metode pendekatan deskriptif-analitis. Hasil penelitian menunjukan, Corak Tafsir Muhammadiyah adalah tafsîr bi al-ra'yi yang dikenal di kalangan Muhammadiyah dengan tafsir yang bersifat ijtihadi (pemikiran), sehingga dalam perkembangan penafsirannya tidak hanya menggunakan pendapat para ulama semata, namun juga menginterkoneksikan dan mengkorelasikan dengan ayat lain, hadis Nabi, pendapat sahabat dan tab'in. Dua metode yang digunakan dalam mengantarkan penafsirannya adalah metode maud $\hat{u}$ 'i dan tahlîli. Penafsiran tersebut dilakukan Muhammadiyah agar al-Qur'an benar-benar menjadi ŝâlihun li kulli zamânin wa makânin (sesuai dengan segala waktu dan tempat), sehingga ajarannya dapat dipahami dan aplikasikan dalam kehidupan nyata.
\end{abstract}

Kata Kunci: Penafsiran, Metode, Tafsir, Muhammadiyah, Corak 


\section{Pendahuluan}

Muhammadiyah merupakan gerakan Islam, dakwah amar ma'ruf nahi munkar, beraqidah Islam dan bersumber pada al-Qur'an dan Sunnah, didirikan oleh KH. Ahmad Dahlan pada tanggal 08 Zulhijjah 1330 bertepatan dengan tanggal 10 November $1912 .{ }^{1}$ Untuk melaksanakan hal tersebut Muhammadiyah membentuk Majelis yang bergerak di bidang keagamaan, yakni lembaga yang menghimpun para ulama yang secara kontinu mengadakan permusyawaratan dan memberi fatwa di bidang keagamaan serta memberi tuntunan mengenai hukum yang sangat bermanfaat bagi khalayak umum. ${ }^{2}$ Majelis tersebut dikenal dengan Majelis Tarjih dan Tajdid Pimpinan Pusat Muhammadiyah.

Dalam merespons tantangan zaman, Muhammadiyah mulai mengembangkan pemahaman terhadap al-Qur'an dengan mengadakan kajian tafsir sebagai cara untuk mendapatkan sebuah keterangan yang jelas dari al-Qur'an, karena al-Qur'an bersifat mujmal (global) sehingga perlu penafsiran secara tafsîll (terperinci). Penafsiran al-Qur'an yang dikembangkan oleh para ulama dibagi menjadi dua corak, yaitu: Pertama, penafsiran ayat alQur'an yang didasarkan pada kutipan yang sahih dengan urutan-urutan yang telah disebutkan di dalam syarat-syarat tafsir, yakni penafsiran dengan al-Qur' an, hadis, pendapat para sahabat, dan para tabi'in terkemuka, atau disebut tafsîr bi al-ma'tsûr. ${ }^{3}$ Kedua, penafsiran yang menjelaskan maknanya (al-Qur'an) didasarkan pemahaman sendiri dan istinbât (penyimpulan) ra'yu semata, atau disebut tafsîr bi al-ra'yi. ${ }^{4}$ Penafsiran al-Qur'an yang didasarkan pada dua corak penafsiran, baik bi al-ma'tsûr maupun bi al-ra'yi telah banyak dikembangkan oleh para

${ }^{1}$ Mustafa Kamal Pasha, Ahmad Adabi Darban, Muhammadiyah Sebagai Gerakan Islam (Yogyakarta: Pustaka SM, 2009), 99.

'Ibid., 116.

${ }^{3}$ Mana' al-Qattân, Mabâhits fi 'Ulûm al-Qur'ân, Juz 1 (Riyâd: Dâr al-Su'ûdiyah, t.th.), 299.

${ }^{4}$ Ibid., 303. muffasir,${ }^{5}$ termasuk mufassir Muhammadiyah, seperti Tafsir Al-Hidayah (tafsir tematik) karya Sa'ad Abdul Wahid, ${ }^{6}$ Tafsir Al-Azhar karya Hamka, ${ }^{7}$ Tafsir Qur'an al-Nûr karya Hasby Ash-Shidiqy, dan Tafsir Sinar karya Abdul Malik Ahmad.

Berdasarkan uraian di atas, beberapa karya tafsir yang lahir dari tokoh-tokoh Muhammadiyah adalah pengembangan dari pemikiran mereka yang dituangkan dalam sebuah karya tafsir. Seiring dengan perkembangan zaman, Muhammadiyah membuat karya tafsir, yaitu Tafsir al-Qoer'an dan Tafsir Tematik al-Qur'an tentang Hubungan Sosial Antar Umat Beragama. Keduanya dirancang dan dibuat untuk memberikan pengetahuan yang bersifat komprehensif, dan pemahaman yang utuh, bukan berdasarkan pada Qîla wa Qâla (apa kata orang). Berdasarkan dua hal tersebut, peneliti membagi rumusan masalah menjadi dua poin penting, yaitu: Bagaimana karakteristik corak tafsir Muhammadiyah?, dan kitab-kitab tafsir apa yang dijadikan rujukan oleh Muhammadiyah dalam melakukan studi pemahaman dan penafsiran terhadap ayat al-Qur'an?

\footnotetext{
${ }^{5}$ Kategori corak tafsir yang dikarang oleh para ulama, Tafsîr $b i$ al-Ma tsûr: Tafsîr ibnu Jarîr al-Tabari, tafsîr abi al-Laits alSamarqandi, al-Daur al-Mantsûr fi Tafsir bi al-Mantsûr, Tafsîr Ibnu Katsîr, Tafsîr al-Baghawi, dan lain-lain, sedangkan Tafsîr bi al-ra'yi: Tafsîr al-Râzi, Tafsîr al-Khâzin, Tafsîr al-Nasafi, Tafsir al-Baidâwi dan lain-lain. Lihat Muhammad Abd al-'Ażîm alZarqâni, Manâhi al- 'Irfân fi 'Ulûm al-Qur'ân (Beirût: Dâr al-Kitâb al-'Arabi, 1995), 25-26, dan Subhi al-Ŝalih, Mabâhits fi 'Ulûm alQur'ân (Beirût: Dâr al-'Ilmu al-Malâyîn, 1977), 292-293.

${ }^{6}$ Tafsir Al-Hidayah pada awalnya masih berupa tulisan di Suara Muhammadiyah, kemudian dibukukan menjadi sebuah karya Tafsir yang beri nama Tafsir Al-Hidayah. Tafsir ini bersifat tematik karena berdasarkan tema diangkat yang kemudian diinterpretasikan atau ditafsirkan dengan penafsiran Ulama abad pertengahan dan abad modern.

${ }^{7}$ Tafsir Al-Azhar yang terdiri dari juz I-XXX merupakan sebuah karya yang sangat monumental dan mulai ditulis pada tahun 1962. Sebagian isi tafsir ini diselesaikan dalam penjara ketika ia menjadi tahanan tahun 1964-1967. Tafsir ini pertama kali dicetak pada tahun 1979, dan telah mengalami beberapa kali cetakan, bahkan tafsir ini bukan hanya diterbitkan di Indonesia akan tetapi juga di Singapura. Tafsir ini pada awal merupakan kumpulan ceramah kuliah subuh yang dilakukan di Masjid Agung Al-Azhar Kebayoran Baru, kemudian besarnya perhatian umat terhadap pelajaran tafsir yang disuguhkan, kemudian dibukukan ke dalam sebuah karya tafsir yang diberi nama Tafsir Al-Azhar, karena ide kupasan tafsir ini diawali di Masjid Al-Azhar. Lihat Samsul Nizar, Memperbincangkan Dinamika Intelektual dan Pemikiran HAMKA tentang Pendidikan Islam (Jakarta: Kencana, 2008), 50.
} 
Dalam melakukan penelitian ini, peneliti menggunakan metode library research, yakni penelitian yang didasarkan pada buku-buku kepustakaan. Buku primer yang dijadikan acuan adalah buku tafsir karya Muhammadiyah, sedangkan buku-buku sekundernya adalah bukubuku pendukung dari berbagai tulisan, seperti buku teks baik Indonesia maupun Arab, artikel jurnal, kamus bahasa Arab, dan lain-lain. Metode pendekatan yang digunakan adalah deskriptifanalitis, yaitu mendeskripsikan sumber data yang ada, kemudian dianalisis dan diinterpretasikan dengan menggunakan sumber data sekunder.

\section{Karakteristik Corak Tafsir}

Muhammadiyah dalam menafsirkan alQur'an memiliki karakteristik corak sendiri yang dikembangkan dalam studi al-Qur'an, yaitu dengan menggunakan corak tafsir bi alra'yi yang didasarkan pada pemikiran. Istilah al-ra'yu dekat maknanya dengan bentuk ijtihad (kebebasan penggunaan akal atau logika) yang didasarkan atas prinsip-prinsip yang benar, menggunakan akal sehat dan persyaratan yang ketat. Sandaran yang dipakai adalah bahasa, budaya Arab yang terkandung di dalamnya, pengetahuan tentang gaya bahasa sehari-hari, dan kesadaran akan pentingnya sains yang amat diperlukan oleh mereka yang ingin menafsirkan al-Qur'an. ${ }^{8}$ Ijtihad berasal dari bahasa Arab, yaitu ijtahâda-yajtahidu-ijtihâdan, memiliki arti mencurahkan segenap kemampuan dan kesungguhan. ${ }^{9}$ Sedangkan menurut istilah, para

\footnotetext{
${ }^{8}$ Muhammad Zaini, "Sumber-sumber Penafsiran al-Qur'an," Substantia 14, no. 1 (2012): 32. Imam al-Dzahabi juga menjelaskan bahwa dimaksud al-ra'yi adalah ijtihad, yaitu ungkapan penafsiran al-Qur'an dengan menggunakan ijtihad setelah mengetahui dari penjelasan bahasa Arab, beberapa aspeknya, lafaz-lafaz bahasa Arab, beberapa aspek penunjukkannya, sebab turunnya al-Qur'an, nâsikh wa mansûkh dan berapa hal yang dijadikan alat untuk menafsirkan al-Qur'an. Lihat Muhammad husain al-Dzahabi, al-Tafsir wa al-Mufassirun (Kairo: Maktabah Wahbah, 2000), 183.

${ }^{9}$ Muhammad bin Abi Bakar bin Abdul Qâdir al-Râzi, Mukhtâr al$\underline{\text { Sihhah }}$ (Kairo: Dâr al-hadîts, 2008), 70. Lihat juga Syauqi Dayyif, dkk, al-Mu'jam al-Wasît, Juz 1 (Kairo: Maktabah Syurûq alDawliyah, 2004), 142.
}

ulama ushul mendefinisikan bahwa Ijtihad adalah mencurahkan dengan segenap kesungguhan dan kemampuan dalam melakukan istinbat hukum yang bersifat alami dari dalil-dalil yang terperinci. Sebagian ulama lain mengatakan bahwa Ijtihad adalah mengerahkan dan mencurahkan segenap kemampuan dalam istinbat (menggali) hukumhukum syar'i yang dilakukan secara bertahap. ${ }^{10}$

Menurut Muhammadiyah, corak penafsiran dengan Ijtihad ( $\left.\mathrm{ra}^{\prime} \mathrm{yu}\right)$ adalah menafsirkan alQur'an dengan mencurahkan segenap kesungguhan seorang mujtahid dalam mendapatkan hukum syara' amali dengan satu metode. Pengertian tersebut didasarkan pada kenyataan yang dihadapi kaum muslimin sejak masa Nabi Muhammad SAW. ${ }^{11}$

Dalam penjelasan tersebut dipahami bahwa corak penafsiran Muhammadiyah adalah corak tafsir bi al-ra'yi yang merupakan sebuah cara untuk memahami ayat al-Qur'an dengan mencurahkan seluruh kemampuan untuk memperoleh sebuah pemahaman yang komprehensif dalam berbagai aspek, yakni aspek akidah, akhlak, ibadah, dan mu'amalah duniawiah.

Pada masa Nabi Muhammad SAW, orang mengharapkan informasi ketentuan agama dari wahyu, baik dari al-Qur'an maupun hadis yang dimulai dengan suatu pertanyaan sahabat kepada Nabi Muhammad, beliaupun menjawab dengan jawaban berdasar al-Qur'an dan al-Sunah. Jika tidak, maka al-Qur'an memberikan arahan agar kaum muslimin melakukan istinbaț, yakni menafsirkan dengan menggunakan penjelasan rasul yakni sunnah al-maqbulah.

Corak Tafsir Muhammadiyah yang menggunakan pemikiran atau Ijtihad tersebut didasarkan pada sabda hadis Nabi Muhammad SAW : ${ }^{12}$

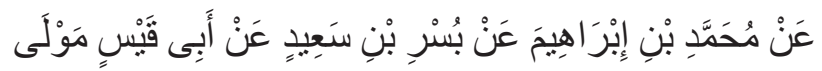

\footnotetext{
${ }^{10}$ Muhammad Abu Zahrah, Us $u \hat{l} l$ Fiqh (Kairo: Dâr al-Fikr alArabi, 1958), 379.

${ }^{11}$ Asjmuni Abdurrahman, Manhaj Tarjih Muhammadiyah: Metodologi dan Aplikasi (Yogyakarta: Pustaka Pelajar, 2007), 104.

${ }^{12}$ Ibid., 105.
} 
عَمْرِو بْنِ الْعَاصِ عَنْ عَمْرِو بْنِ الْعَاصِ أَنَّهُه سَمِعَ رَسُولَ اللَّهِ

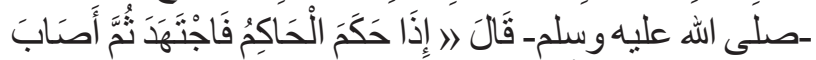

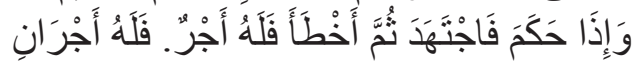

"Dari Muhammad bin Ibrâhîm dari Busr bin Sa'îd dari Abi Qais yakni mantan budak 'Amr bin 'Âs dari Amr bin 'Âs, bahwasanya ia mendengar Rasulullah SAW bersabda: apabila hakim menetapkan hukum dan berijtihad, apabila benar ijtihadnya, ia mendapatkan dua pahala, apabila seorang hakim berhukum dengan berijtihad dan ijtihadnya salah, maka ia mendapatkan satu pahala". ${ }^{13}$

Berdasarkan hadis tersebut, bahwa corak penafsiran atau tafsir Muhammadiyah adalah $b i$ al-ra'yi dan dikenal di kalangan Muhammadiyah dengan istilah Ijtihad, sehingga dalam menafsirkan al-Qur'an yang berkaitan dengan masalah hukum, berpegang pada pendapat ulama us $\hat{u} l$ yang menempuh tiga cara: (1) Istinbaț, dengan memahami nash yang pasti (qat $i$ ), (2). Ijtihad, dengan memahami terhadap nash yang belum menunjukan hukum satu masalah, dan (3) Ijtihad yang juga digunakan untuk memahami masalah yang hanya ditunjuki oleh jiwa nash, yakni kemaslahatan atau kedamaian.

Rumusan tersebut difokukan dalam tiga bentuk istilah ijtihad, yaitu ijtihâd bayâni, ijtihâd Qiyâsi, dan ijtihâd istis lâhi..$^{14}$ Pertama, Ijtihâd Bayâni, menurut ulama Hanafiyah, ada lima bayan atau keterangan dan menurut sebagian ulama menetapkan satu saja, karena bayân taghyîr dan bayân tabdîl itu dapat dijadikan satu. Bayân dibagi menjadi lima bagian, yaitu sebagai berikut:

1. Bayân taqrîr adalah penjelasan dalam rangka mengungkapkan suatu makna dengan dasardasar lain yang memberikan penjelasan

\footnotetext{
${ }^{13}$ Muslim bin Al-Hajaj Abu Husain al-Qusyairiy al-Naisaburi, Sahîh Muslim, Bâb Bayâni Ajr al-Hâkim, Juz 5 (Riyâd: Bait al-Afkâr al-Dawliyah, 1998), 131. Lihat Muhammad Ismail alBukhâri, Sahîh al-Bukhâri, Kitâb Ba'i al-Wahyi, Juz, 9 (Beirût: Dâr Thûq al-Najâh, 1422), 132.

${ }^{14}$ Asjmuni Abdurrahman, 105.
}

yang komprehensif mengenai (ayat) yang dimaksud, baik antara makna kata maupun ungkapan dalam nash atau dalil.

فَسَجَدَ الْمَلَائكِكَةُ كُلُْهُمْ أَجْمَعُونَنَ (73)

\section{“Lalupara Malaikat bersujud semuanya."}

Kata Malâikat mengandung makna umum yaitu seluruh malaikat yang ditegaskan dalam kata "Kulluhum Ajma'ûn” (seluruhnya).

2. Bayân Tafsîr, adalah penjelasan suatu lafal atau kata-kata. Sehingga nash tersebut menjadi lebih jelas maksudnya, seperti mujmal menjadi mufasal, musytarak, khafi. Sebagaimana dalam surat al-Baqarah ayat 43 sebagai berikut:

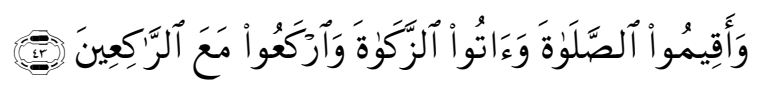

"Dan dirikanlah shalat, tunaikanlah zakat dan rukuklah beserta orang-orang yang rukuk".

Makna ayat tersebut masih bersifat mujmal, maka dapat dijelaskan dengan sabda Nabi SAW sebagai berikut:

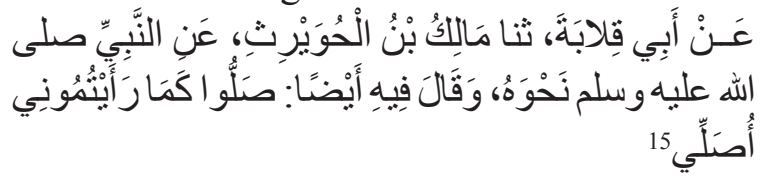

"Dari Abi Qilâbah, telah menceritakan kepada kami Mâlik bin Huwairîts akan hadis yang sama dari Nabi SAW dan beliau bersabda: Hendaklah kamu shalat sebagaimana kamu melihat shalat-ku”.

3. Bayân Taghyîr, adalah keterangan-keterangan

\footnotetext{
${ }^{15}$ Ali bin Umar al-Dâruquthni, Sunan al-Dâruquthni, Juz 1 (Beirût: Al-Muassasah al-Risâlah, 2004), 273. Lihat juga Abdullah bin Abdurrahman bin Fadhl bin Bahrâm al-Dârimi, Sunan al-Dârimi, Juz 1 (Riyâd: Dâr al-Mughni, 2000), 318; Ahmad Muhammad Syakir, Al-Musnad li Imam Ahmad bin Muhammad bin Hanbal, Juz 2 (Kairo: Dâr al-hadîts. 1995), 141; Muhammad bin Ismail al-Bukhari, $\underline{\text { Sahîh }}$ al-Bukhâri, Juz 8 (Beirût: Dâr Ibnu Kasîr), 9.
} 
yang mengubah dari makna żahir menjadi makna yang dituju, seperti kata yang mengandung pengecualian atau ististna. Dalam hal ini usaha yang dilakukan adalah mencari mukhas $\underline{\text { is }}$ dari makna yang umum. Sebagai contoh ististna dalam al-Qur'an surat al-Nahl ayat 106 sebagai berikut:

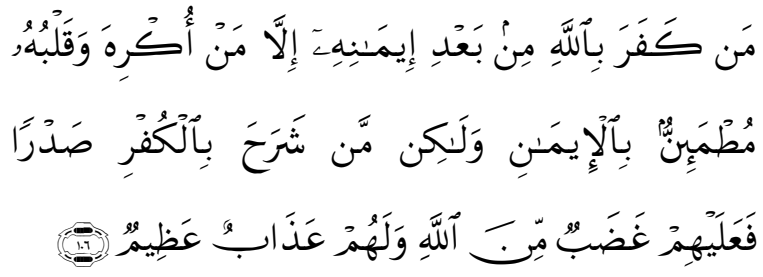

"Barang siapa yang kafir kepada Allah setelah dia beriman (dia mendapatkan kemurkaan Allah) kecuali orang-orang yang dipaksa kafir padahal hatinya tetap tenang dalam beriman (dia tidak berdosa), tetapi orang yang melapangkan dadanya untuk kekafiran, maka kemurkaan Allah menimpanya dan mereka akan mendapat azab yang besar".

Dalam ayat ini dijelaskan bahwa orangorang kafir setelah beriman (murtad) akan mendapatkan murka Allah, kecuali kekafirannya dipaksa, sedangkan hatinya tetap beriman.

4. Bayân Tabdîl, adalah usaha mencari penjelasan dengan jalan nasakh. Maksudnya, mencari apakah ada nâsikh mansûkh dalam hukum masalah yang dicari oleh seorang mujtahid. Masalah nâsikh mansûkh itu diperlukan dalam hadis, karena dalam al-Qur'an akhirakhir ini berkembang lagi pendapat bahwa tidak ada nâsikh mansûkh dalam al-Qur'an, yang ada hanya mengkhususkan ayat-ayat yang masih umum. Maka dalam nâsikh wa mansûkh hanya ada pada hadis Nabi SAW, sebagaimana dahulu Nabi Muhammad SAW melarang ziarah kubur kemudian beliau membolehkannya.

5. Bayân Darûrah, adalah keterangan yang tidak disebutkan, tetapi tidak boleh harus diungkapkan. Artinya bayân tersebut tidak berupa kata-kata, tetapi sesuatu yang didiamkan (Dalâlah al-Sukûti). Sebagaimana dalam surat al-Nisa' ayat 11 sebagai berikut:

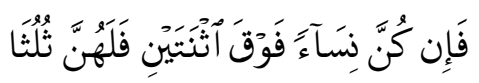

"Jika yang meninggal mempunyai anak dan dia diwarisi oleh ibu bapaknya (saja), maka ibunya mendapat sepertiga".

Dalam ayat tersebut tidak disebutkan bagian ayah. Padahal warisan itu untuk kedua orang tua, maka bagian ayah adalah sisanya.

Kedua, Ijtihâd Qiyâsi. Ijtihad ini dilakukan untuk mendapatkan hukum suatu masalah yang tidak ada nashnya secara langsung, seperti menghisap ganja. Tetapi ada nash al-Qur'an maupun al-sunnah yang menunjukan keharaman ganja, seperti keharaman khamr. Berdasarkan masalah yang akan dicari sumber hukumnya, seperti menghisap ganja, tidak didapati dalam alQur'an maupun al-sunnah, yang ada kesamaannya adalah larangan al-Qur'an tentang khamr. Menyamakan hukum keharaman ganja dengan keharaman khamr, menurut ahli ushul disebut menetapkan hukum berdasarkan qiyâs (analogi, menurut ilmu logika/mantiq).

Ketiga, ijtihâd istis lâh $\underline{i}$ adalah ijtihad dalam usaha mendapatkan hukum yang tidak ada nash langsung yang mengandung hukum masalah yang dicari, dengan mendasarkan masalah yang akan dicapai. Ijtihâd istis $\underline{\text { lâh }} \underline{i}$ dapat ditempuh dengan tiga metode, yaitu: (1) metode istihsân, yaitu mengecualikan dari qiyâs yang berdasarkan 'illat Jalî menggunakan qiyâs khafi, dan mengecualikan dari nash umum yang melarang dengan membolehkan karena adanya kemaslahatan yang akan dicapai atas dasar darûrat maupun menghindari kesempitan (raf'u al-harâj). (2) metode saddu al-dzarâ'i, yaitu menutup sesuatu yang menuju kepada kerusakan. (3) metode isti $\underline{s} l a \hat{h}$, yaitu mencari ketentuan suatu masalah yang tidak ada ketentuan hukumnya 
berdasarkan nash, baik yang melarang maupun yang memerintah dengan dasar kemaslahatan yang dicapai. Kemaslahatan yang ingin dicari yaitu maslahah mursalah. (4) menetapkan hukum sesuatu didasarkan pada kebiasaan yang telah ada, berlaku, mendatangkan manfaat dan tidak dilarang oleh nash serta tidak mendatangkan mafsadah yang lebih besar. (5) ijtihad dalam menafsirkan ayat-ayat kauniyah, yaitu menafsirkan ayat yang mengandung sunatullah seperti gejala alam. Dalam memahami ayat-ayat kauniyah dilakukan sesuai dengan perkembangan ilmu pengetahuan dan teknologi.

Dalam hal tersebut sebagaimana penafsiran Muhammad Abduh terhadap ayat-ayat al-Qur'an yang bisa dijadikan rujukan, yaitu berpegang teguh pada bahasa arab, menggunakan nash hadis rasul yang $\underline{S} a \underline{h} \underline{\hat{h}} \underline{h}$ dengan melakukan ijtihad dan selalu menyesuaikan antara ayat dengan ilmu pengetahuan modern yang tentu saja membawa maslahah (kebaikan).

\section{Metode dalam Corak Tafsir}

Metode dalam corak tafsir merupakan suatu cara untuk mendapatkan penjelasan makna yang terkandung dari ayat-ayat al-Qur'an, sehingga dapat diterima dan dimengerti oleh setiap orang yang mengkajinya. Di antara metode yang digunakan oleh Muhammadiyah dalam menafsirkan ayat al-Qur'an, sebagai berikut:

a. Metode Maud $\hat{u}^{\prime} i$

Muhammadiyah dalam memahami dan menafsirkan al-Qur'an selain menggunakan metode ijtihâd juga bisa menggunakan metode maudû' $i$. Metode maud $\underline{u}$ ' $i$ adalah membahas ayat-ayat al-Qur' an sesuai data dengan tema atau judul yang telah ditetapkan. Semua ayat berkaitan dengan topik tersebut dihimpun kemudian dikaji secara mendalam dan tuntas dari segala aspeknya seperti asbâb al-Nuzûl, kosa kata, istinbât (penetapan) hukum, dan lain-lain. ${ }^{16}$

\footnotetext{
${ }^{16}$ Nashruddin Baidan, Metode Penafsiran Al-Qur'an: Kajian Kritis Terhadap Ayat-ayat yang Beredaksi Mirip (Jakarta: Pustaka Pelajar, 2011), 72.
}

Menurut M. Quraish Shihab, metode maud $\hat{u}$ ' $i$ walaupun benihnya telah dikenal sejak masa Rasulullah SAW, namun ia baru berkembang jauh sesudah masa beliau. Metode ini dikenal sejak tafsîr al-Farra (w $206 \mathrm{H}$ ), atau Ibnu Mâjah (w 273 H), atau tafsîr al-Thabari (w $310 \mathrm{H}$ ). Dalam perkembangannya metode maud $\hat{u}$ 'i mengambil dua bentuk penyajian, yaitu; penyajian pertama, menyajikan kotak yang berisi pesan-pesan al-Qur'an yang terdapat pada ayat yang terangkum dalam satu surat saja. Misalnya, pesan-pesan dalam surat al-Baqarah, surat Ali Imran, surat Yasin dan sebagainya. Biasanya kandungan pesan tersebut diisyaratkan oleh nama surat yang dirangkum pesannya, selama nama tersebut bersumber dari Rasulullah SAW. ${ }^{17}$

Sebagai contoh, surat al-Kahfi yang arti harfiahnya adalah gua. Dalam uraiannya, gua tersebut dijadikan tempat perlindungan sekelompok pemuda yang menghindar dari kekejaman penguasa pada zamannya. Dari nama ini diketahui bahwa surat tersebut dapat memberi perlindungan bagi yang menghayati dan mengamalkan pesanpesannya. Dari sinilah setiap ayat atau kelompok ayat yang terdapat dalam surat al-Kahfi, diupayakan mengkaitan dengan makna perlindungan. ${ }^{18}$

Bentuk penyajian yang kedua, metode maud $\hat{u}^{\prime} i$ mulai berkembang pada tahun enam puluhan. Disadari oleh pakar bahwa menghimpun pesan-pesan al-Qur'an yang terdapat pada satu surat saja, belum menuntaskan persoalan. Bukanlah masih ada pesan-pesan yang sama atau yang berkaitan erat dengannya pada surat-surat yang lain?. Kalau demikian mengapa tidak menghimpun saja pesan-pesan yang terdapat dalam berbagai surat lainnya?. ${ }^{19}$

\footnotetext{
${ }^{17}$ M. Quraish Shihab, Wawasan Al-Qur'an: Tafsir Maudhu'i atas Pelbagai Persoalan Umat (Bandung: Mizan, 1998), xii-xiii. ${ }^{18}$ Ibid., xiii.

${ }^{19}$ Ibid., xiii
} 
Metode ini kemudian diterapkan oleh Muhammadiyah dalam sebuah karya tafsir, yaitu "Tafsir Tematik al-Qur'an tentang Hubungan Sosial Antar Umat Beragama" yang disusun oleh Majelis Tarjih dan Pengembangan Pemikiran Islam Pimpinan Pusat Muhammadiyah. Pengembangan Pemikiran Islam di lingkungan persyarikatan Muhammadiyah pasca Muktamar Banda Aceh 1995 masih tetap mengacu kepada hubungan timbal balik yang kritis antara normativitas wahyu dan historisitas pemahamannya, baik era klasik, skolastik, modern, dan lebihlebih lagi era modern tingkat lanjut. Dalam hal ini yang menjadi titik tekan adalah historisitas pemikiran keagamaan Islam dalam menghadapi berbagai isu dan perkembangan keilmuan, kebudayaan, dan keagamaan kontemporer dengan tetap mengacu kepada normativitas wahyu yang bersifat Rahmatan lil 'Âlamîn dan Syifấ' lima fi al-sidûr. ${ }^{20}$

Berdasarkan hal tersebut, Majelis Tarjih dan Pengembangan Pemikiran Islam Pimpinan Pusat Muhammadiyah mencoba (sebagai langkah awal) menyusun sebuah tafsir tematis yang menghimpun sejumlah ayat dari berbagai surat dalam al-Qur'an yang berbicara masalah yang sama untuk dihimpun dan disusun sedemikian rupa kemudian diberi tema dan ditafsirkan. Tafsir tematis tersebut disusun dengan langkah-langkah sebagai berikut: ${ }^{21}$

1. Menyusun tema-tema yang diangkat dalam tafsir.

2. Menyeleksi ayat-ayat yang terkait dengan tema kerukunan umat beragama.

3. Setelah jelas sub tema bahasan berikutnya, ayat-ayatnya kemudian ditafsirkan dengan memperhatikan: (a) Munâsabah (korelasi)

${ }^{20}$ Majelis Tarjih dan Pengembangan Pemikiran Islam PP Muhammadiyah, Tafsir Tematik Al-Qur'an tentang Hubungan Sosial Antarumat Beragama (Yogyakarta: Pustaka SM, 2000), x. ${ }^{21}$ Ibid., xiii-xv. ayat dengan ayat lain dalam konteks yang se-tema. (b) Menghimpun hadis-hadis yang terkait dengan tema dan juga datadata sejarah yang diperlukan, khususnya latar belakang turunnya ayat (sabâb al-Nuzîl) sepanjang diperlukan dan riwayatnya diterima.

Adapun pendekatan yang digunakan dalam menafsirkan ayat al-Qur'an adalah dengan pendekatan kontekstual. Maksudnya adalah kontektualisasi ayat-ayat al-Qur'an dalam tafsir ini dilakukan dengan cara gerak bolak-balik hermeneutis untuk menemukan keseimbangan antara tuntutan praktis dan universalitas makna teks.

Kitab-kitab tafsir yang dijadikan sebagai sumber rujukan dalam tafsir tematis tersebut adalah kitab-kitab tafsir klasik yang mu'tabar (direkomendasikan), seperti Tafsîr al-Thabari, Tafsîr al-Mâwardi, Tafsîr al-Kasyâf, Tafsîr al-Qurtûbi, Tafsîr al-Muharrar al-Wajîz, Tafsîr Bahr al-Muhît, Tafsîr al-Baghawi, Tafsîr Ibnu Taimiyyah, Tafsîr al-Wâhidi. Kemudian tafsir abad 20, seperti Tafsîr alManâr dan al-Mîzân the Holy Qur'an. Selain itu, untuk menganalisis kosa kata digunakan karya-karya Leksikografi Arab, seperti Lisân al-Arab, Mu'jam Mufradât al-Fâzh alQur'an, Tahdzîbal-Lughah, Mu'jam Maqâyis al-Lughah dan al-Mu'jam al-Wasît. Selain itu juga menggunakan kitab-kitab Hadis, Fikih dan Usîl al-Fiqh.

Buku ini terdiri atas empat bab, yaitu: Bab I, mengkaji prinsip-prinsip hubungan sosial antar umat beragama yang di dalamnya dikemukakan tafsir mengenai sejumlah ayat yang dapat dipahami sebagai pengakuan Islam terhadap kenyataan keragaman agama dan bagaimana konsistensi damai dalam hubungan antar umat beragama dapat diwujudkan. Bab II, menafsirkan ayat-ayat yang berkaitan dengan menjaga hubungan baik dan kerjasama antar umat beragama. Bab III, konsep Ahl 
al-Kitâb, dan Bab IV, membahas satu topik khusus yaitu kawin beda agama dalam alQur'an.

b. Metode Tahlîli (Analitis)

Metode tahlîli adalah menafsirkan ayat alQur'an dengan memaparkan berbagai aspek yang terkandung di dalam ayat-ayat yang sedang ditafsirkan serta menerangkan maknamakna yang ada di dalamnya sesuai dengan keahlian dan kecenderungan dari mufasir yang menafsirkan ayat-ayat tersebut. ${ }^{22}$ Dalam menerapkan metode ini biasanya mufasir menguraikan makna yang terkandung dalam al-Qur'an, ayat demi ayat dan surat demi surat sesuai dengan urutan mushhaf.

Metode tahlîli ini dinamai oleh Baqir al-Shadir sebagai metode $\operatorname{tajz}_{\hat{\imath}}{ }^{\prime} i$ adalah satu metode tafsir di mana seorang mufasir menjelaskan kandungan ayat-ayat al-Qur'an dari berbagai segi dengan memperhatikan runtutan ayat sebagaimana tercantum dalam mushaf. Seorang pemikir al-Jazair kontemporer, Malik bin Nabi menilai bahwa upaya para ulama menafsirkan al-Qur'an dengan menggunakan metode tahlîli tidak lain kecuali dalam rangka upaya mereka untuk meletakan dasar-dasar rasional bagi pemahaman kemu'jizatan al-Qur'an. ${ }^{23}$

Metode ini mengurai kosa kata lafżiyah dan menjelaskan arti yang dikehendaki dengan memperhatikan unsur-unsur balâghah, i'jâz dan isi kandungannya dari aspek pengetahuan dan hukum. Metode penafsiran yang seperti ini juga tidak mengabaikan aspek historis atau asbâb al-Nuzûl mikro dan munâsabah antara satu ayat dengan ayat lain. Pembahasannya merujuk pada riwayat dari Nabi, sahabat dan ungkapan-ungkapan pra Islam dan kisah isrâ'iliyat. Oleh karena itu, pembahasannya cukup luas dan tidak menutup kemungkinan

\footnotetext{
${ }^{22}$ Nashruddin Baidan, 68.

${ }^{23}$ M. Quraish Shihab, Membumikan Al-Qur'an: Fungi dan Peran wahyu dalam Kehidupan Masyarakat (Bandung: Mizan, 1999), 86.
}

penafsirannya menjadi bias karena diwarnai oleh subjektivitas mufasir, baik latar belakang keilmuannya maupun mazhab tafsir yang diyakininya sehingga menyebabkan adanya kecenderungan khusus yang diaplikasikan pada karyanya. ${ }^{24}$

Metode ini kemudian diterapkan oleh Muhammadiyah dalam sebuah karya tafsir yakni "Tafsir Al-Qoer'an". Tafsir ini disusun oleh Lajnah Tafsir Pimpinan Pusat Muhammadiyah, yang terdiri dari K.R.H. Hadjid, KH. Mas Mansoer, KH. Farid, dan KH. Ahmad Badawi. Diterbitkan oleh Hoofbestuur Moehammadijah Madjlis Poestaka, Djokjakarta.

Kitab Tafsir Al-Qoer'an tersebut hanya membahas penafsiran surat al-Fatihah dan surat al-Baqarah juz pertama sampai ayat ke-141. Dimulai dengan pendahuluan (muqaddimah), pedoman sumber rujukan dan kandungan surat al-Baqarah juz pertama yang akan dibahas. Kitab ini membahas berbagai aspek di dalamnya dengan merujuk kepada kitab-kitab tafsir dan hadis sebagai penguat penjelasan suatu ayat yang ditafsirkan. Tafsir ini sangat unik karena ditulis dengan huruf Jawa (tulisan Jawa berbahasa Indonesia).

Dalam Tafsir Qoer'an tersebut, pertama mencantumkan ayat berdasarkan urutannya, kemudian mengartikan kosa kata dari sebuah ayat secara bahasa maupun secara istilah, yang selanjutkan dijelaskan dengan mengutip atsar sahabat dan hadis Nabi SAW, akan tetapi tidak semua ayat ditafsirkan demikian hanya beberapa ayat saja. Sedangkan selainnya ditafsirkan dengan pendapat individu berdasarkan pengetahuannya dan juga mengambil pendapat para ulama tafsir, hal ini terlihat dalam rujukan penafsirannya.

Adapun kitab-kitab tafsir yang menjadi rujukan dalam kitab Tafsir Qoer'an adalah sebagai berikut:

${ }^{24} \mathrm{M}$. Alfatih Suryadilaga, dkk, Metodologi Ilmu Tafsir (Yogyakarta: Teras, 2005), 42. 
1. Tafsîr al-Kasyâf, karya al-Zamakhsyari, $528 \mathrm{H}$.

2. Tafsîr al-Intishâf, karya Nâsiruddîn, $683 \mathrm{H}$

3. Tafsîr Hasyiyah al-Fâiqah, karya Muhammad Ali, $816 \mathrm{H}$.

4. Tafsîr Madârik al-Tanzîl, karya al-Nasafi, $701 \mathrm{H}$.

5. Tafsîr A $\underline{h a} a ̂ m$, Karya Abu Bakar alAndalusi, $542 \mathrm{H}$.

6. Tafsîr Fath al-Qadîr, karya Al-Syaukâni, $1250 \mathrm{H}$.

7. Tafsîr al-Manâr, karya Muhammad Rasyîd Ridha, 1358 H.

8. Tafsîr Jawâhir al-Qur'ân, karya Tantawi Jauhari, $1359 \mathrm{H}$.

9. Tafsîr Ruh al-Ma'âni, karya Al-Alusi, $1270 \mathrm{H}$.

10. Tafsîr Bahr al-Muhît, karya Abu Hayyân, $745 \mathrm{H}$.

11. Tafsîr Al-Na $\underline{h} r$ al-Ma'âd, karya Abu Hayyân, $745 \mathrm{H}$.

12. Tafsîr Al-Dâr al-Lâqith, karya Tajuddîn, $749 \mathrm{H}$.

13. Tafsîr Jâmi' al-Bayân, karya Al-Tabari, $310 \mathrm{H}$.

14. Tafsîr Anwâr al-Tanzîl, karya Baidawiy, $791 \mathrm{H}$.

15. Tafsîr Hasyiyah, karya Al-Karûni.

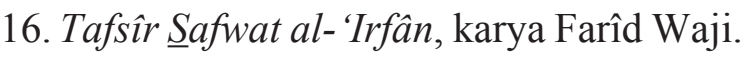

17. Tafsir Mushaf Mufassar, karya Farîd Waji.

18. Tafsîr Gharîb al-Qur'ân, karya Al-Râghib al-Asfahâni.

19. Tafsîr al-Jalâlain, karya Jalāluddîn alMahalli dan Jalâluddin al-Suyûti.

20. Tafsîr Tasturi, karya Tasturi.

Kitab-kitab dan buku-buku pendukung yang dijadikan rujukan selain kitab tafsir adalah sebagai berikut:

1. Dînullâh fî Kutub al-Anbiyâi, karya Taufik

2. Al-Dînu fi Nazzr la-Aqli, karya Taufik.

3. Al-Islâm wan Naśrâniyah, karya Muhammad Abduh.

4. Risâlah al-Tauhîid, karya Muhammad
Abduh.

5. Subhah al-Nasâra, karya Muhammad Abduh.

6. Târîkh al-Ustâdz al-Imân, karya Muhammad Abduh.

7. Al-Wahy al-Muhammadi, karya Muhammad Rasyîd Ridha.

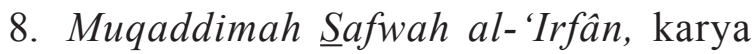
Farîd Waji.

9. Iz hâr al- $\underline{H} a q$, karya Rahmah al-Hindi.

10. Al-Islâm Ruh al-Ilmi wa al-Madâniyah, karya Gulayaini.

11. Kitab Bibel (Perjanjian Lama dan Perjanjian Baru).

12. Injil Barnabas.

13. Hâdhir al-Alami al-Islâmi, karya Lothrof Stodard.

14. Majalah Al-Manâr, Mesir.

15. Bidâyah al-Mujtahid, karya Ibnu Rusyd.

16. Mîzân Sya'rani.

17. Rahmah al-Ummah fí Ikhtilâf al- 'Aimmah.

18. Ihyâ' Ulûm al-Dîn, karya al-Ghazali.

19. $\underline{\text { Sahîh }}$ al-Bukhâri, karya Imam Al-Bukhâri.

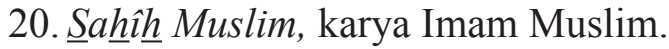

21. Sunan Abu Dâwud, karya Abu Daud,

22. Kitab Fikih, dan kitab hadis dan lain-lain.

\section{Corak Tafsir Muhammadiyah}

Berdasarkan dua metode dalam corak tafsir yang dikembangkan Muhammadiyah untuk memahami ayat al-Qur'an, tampak jelas corak penafsiran yang digunakan, termasuk kategori corak tafsîr $b i$ al-Ra'yi karena lebih banyak menggunakan rasio (pemikiran dan ijtihad) untuk mendapatkan sebuah penjelasan yang lebih rinci dari ayat al-Qur'an.

Tafsîr bi al-ra'yi disebut juga tafsîr bi alma'qûl atau tafsir berdasarkan ijtihad. Jadi, tafsîr bi al-ra'yi adalah ijtihad yang dibangun di atas dasar-dasar yang benar dan kaidah-kaidah lurus yang harus digunakan oleh setiap orang yang menafsirkan kitab Allah atau menggali maknamaknanya. Oleh karena itu, tafsir bi al-ra'yi dalam Muhammadiyah bukan tafsir yang sekedar menggunakan pendapat atau hawa nafsu semata 
atau berdasarkan pikiran yang terlintas apalagi semaunya saja, tetapi menggunakan metodemetode penafsiran yang tidak meninggalkan nash al-Qur'an dan hadis. ${ }^{25}$

Imam al-Qurthubi mengatakan, bahwa barang siapa yang mengatakan sesuatu perkara dalam al-Qur'an dengan keraguan yang terlintas dalam pikirannya atau dalam hatinya tanpa mengambil atau berdasarkan dalil yang pokok, maka dia salah dan tercela. Akan tetapi barang siapa yang mengambil istinbat suatu hukum dengan membawanya kepada dasar-dasar kesempurnaan yang telah disepakati maknanya, maka ia adalah orang yang terpuji. ${ }^{26}$

Dalam hal ini orang yang sengaja mengatakan sesuatu perkara darial-Qur'an, padahal ia mengetahui bahwa itu salah, maka ia akan disiapkan tempat duduk dari neraka. Artinya, dalam menafsirkan al-Qur'an tidak semata-mata hasil dari pikiran semata, akan tetapi menggunakan pemikiran yang murni bersih dan tidak ada upaya untuk melakukan kebohongan, semata-mata untuk mencari penjelasan suatu perkara berdasarkan kaidah-kaidah yang benar yang tidak menyelisihi ketentuan-ketentuan yang telah ditetapkan Allah SWT.

Lebih lanjut, Muhammadiyah dalam menafsirkan al-Qur'an menggunakan metode tahlîli dalam rangka mendapatkan penjelasan mengenai suatu ayat yang ditafsirkan. Berdasarkan hal tersebut, peneliti menyimpulkan bahwa Tafsir al-Qoer'an adalah termasuk kategori corak bi al$r a$ 'yi sebagaimana yang telah disebutkan di atas, karena dalam tafsir ini sedikit sekali mengutip pendapat sahabat atau sabda Nabi SAW. Hal tersebut tampak jelas dalam beberapa penafsiran ayat yang lebih banyak menggunakan pendapat daripada hadis Nabi dan pendapat para sahabat.

Bentuk penafsiran Muhammadiyah yang cenderung menggunakan corak tafsir bi al-ra'yi berbeda dengan tafsîr bi al-ma'tsûr yang banyak

${ }^{25}$ Muhammad Ali al-Shâbûni, Al-Tibyân fi Ulûm al-Qur'ân (Jakarta: Dâr al-Kutub al-Islâmiyah, 2003), 155.

${ }^{26} \mathrm{Abu}$ Abdillah Muhammad bin Ahmad bin Abi Bakr bin Farh Al-Anshâri al-Khazraji, Tafsîr al-Qurthubi, Juz 1 (Kairo: Dâr alKutub al-Mishriyah, 1964), 33. mengutip atsar dan hadis Nabi Muhammad SAW, karena tafsîr bi al-ma'tsûr adalah sebuah tafsir (penjelasan) yang mencakup semua aspek yang ada dalam al-Qur'an berupa keterangan dan penjelasan sebagian ayat yang dinukil dari Rasulullah SAW, para sahabat, para tabi' in untuk memperoleh penjelasan apa yang maksudkan Allah SWT dari nash-nash al-Qur'an al-Karim. ${ }^{27}$

\section{Contoh-contoh Aplikasi Penafsiran al-Qur'an}

Untuk mendapatkan suatu penjelasan yang lebih komprehensif, maka peneliti memaparkan sebuah contoh penafsiran dari dua tafsir yang telah disebutkan di atas yaitu:

1. Contoh Penafsiran dengan Metode maud $\underline{u}$ ' $i$

Judul yang diangkat adalah tentang "Keadilan dan Persamaan" yang merupakan salah satu prinsip hubungan antar umat beragama. Penafsiran ini dimulai dengan:

a. Teks Ayat

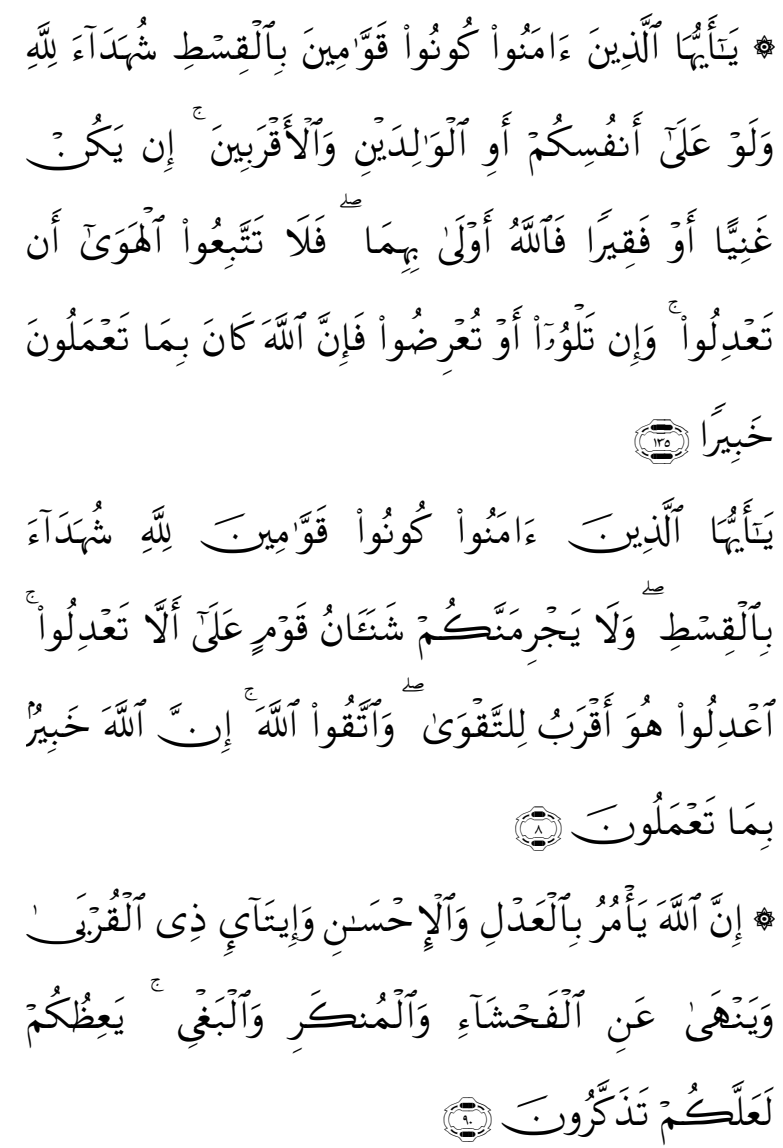

${ }^{27}$ Muhammad Husain al-Dzahabi，Al-Tafsîr wa al-Mufassirûn, Juz 4 (Kairo: Maktabah Wahbah, t.t), 5. 
b. Terjemah Ayat:

"Wahai Orang-orang yang beriman! Jadilah kamu penegak keadilan, menjadi saksi karena Allah, walaupun terhadap dirimu sendiri atau terhadap ibu bapak dan kaum kerabatmu. Jika dia (yang terdakwa) kaya atau miskin, maka Allah lebih tahu kemaslahatan (kebaikannya). Maka janganlah kamu mengikuti hawa nafsu karena ingin menyimpang dari kebenaran. dan jika kamu memutarbalikan (kata-kata) atau enggan menjadi saksi, maka ketahuilah Allah Maha Teliti terhadap segala apa yang kamu kerjakan" (al-Nisa 4: 135). ${ }^{28}$

"Wahai Orang-orang yang beriman! Jadilah kamu sebagai penegak keadilan karena Allah, (ketika) menjadi saksi dengan adil. Dan janganlah kebencianmu terhadap suatu kaum, mendorong kamu untuk berlaku tidak adil. Berlaku adillah. Karena (adil) itu lebih dekat kepada takwa. Dan bertakwalah kepada Allah, sungguh Allah Maha Teliti apa yang kamu kerjakan" (al-Maidah 5: 8).

"Sungguh Allah menyuruh (kamu) berlaku adil dari berbuat kebaikan, memberi bantuan kepada kerabat, dan dia melarang (melakukan) perbuatan keji, kemungkaran dan permusuhan. Dia memberipengajaran kepadamu agar kamu dapat mengambil pelajaran" (al-Nahl 16: 90).

"Sungguh kami telah mengutus rasul-rasul Kami dengan bukti-bukti yang nyata dan Kami turunkan bersama mereka kitab dan neraca (kadilan) agar manusia dapat berlaku adil. Dan Kami menciptakan besi yang mempunyai kekuatan hebat dan banyak manfaat bagi manusia, dan agar Allah mengetahui siapa yang menolong (agama)-Nya dan rasulrasul-Nya walaupun Allah tidak dilihatnya. Sesungguhnya Allah Maha Kuat, lagi Maha Perkasa” (al-Hadid 57: 25).

${ }^{28}$ Departemen Agama RI, Al-Hikmah, Al-Qur'an dan Terjemahnya (Bandung: Diponegoro, 2006), 100.

\section{c. Tafsir Ayat}

Ayat-ayat di atas mengandung tema keadilan. Ayat pertama, kedua, dan ketiga memerintahkan orang-orang beriman agar menjadi penegak dan saksi keadilan sekalipun bertentangan dengan kepentingan pribadi dan kepentingan keluarga, dan juga berlaku adil terhadap orang-orang dibenci. Ayat keempat menyatakan bahwa keadilan adalah prinsip agama yang dibawa oleh semua rasul yang diutus Tuhan. ${ }^{29}$

Perkataan adil berasal dari bahasa Arab yang memiliki arti seimbang dan proporsional. Kata tersebut ada hubungannya dengan kata lain, yakni al-'idl yang artinya salah satu bakul gandaran yang dipikul oleh petani atau dibawa di atas punggung unta. Kalau orang memikul dua buah bakul dengan gandar (kayu pemikul) di mana salah satu bakul diletakkan di muka dan lainnya diletakkan di belakang, maka berat kedua bakul itu harus seimbang agar ia dapat dipikul; jika tidak orang tersebut tidak bisa memikulnya. Bakul tersebut disebut $a l$ - 'idl karena ia seimbang satu sama lain sehingga dapat dipikul atau diletakkan di atas punggung unta. Jadi keadilan itu secara harfiyah menggambarkan adanya perimbangan yang proporsional. ${ }^{30}$

Perintah berbuat adil dalam ayat-ayat di atas sangat umum, karenanya berlaku juga dalam hubungan antar umat beragama. Muhammad Abu Zahrah menyatakan bahwa semua hubungan antar umat manusia dalam Islam berasaskan keadilan, bahkan keadilan terhadap musuh sekalipun. Lawan dari keadilan adalah ketidakadilan (kezaliman), dan Nabi Muhammad SAW dalam sebuah hadis Qudsi menyatakan bahwa Allah SWT berfirman:

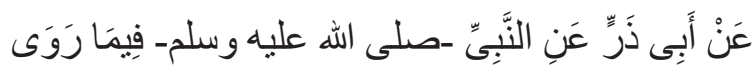

\footnotetext{
${ }^{29}$ Majelis Tarjih dan Pengembangan Pemikiran Islam PP Muhammadiyah, Tafsir Tematik Al-Qur'an tentang Hubungan Sosial Antarumat Beragama, 55.

${ }^{30}$ Ibid., 56.
} 


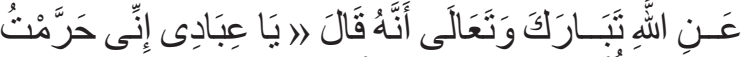

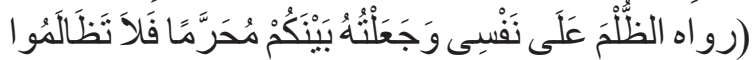

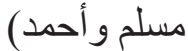

"Wahai hamba-hamba-Ku, sesungguhnya Aku telah mengharamkan ketidakadilan (kezaliman) atas diri-Ku dan Aku telah menjadikannya haram di antara sesamamu. Oleh sebab itu janganlah kamu saling menzalimi (tidak berlaku adil)" (HR. Muslim dan Ahmad). ${ }^{31}$

Perintah berlaku adil dapat dikemukakan dengan menyatakan kata I'dilu lebih tega dari ini adalah dengan kata Kunu Muqsitin dan puncaknya adalah Kûnû Qawwamûna bi al-Qisti, yakni hendaklah secara sempurna dan penuh perhatian kamu menjadi penegak keadilan dengan sifat yang melekat pada diri kamu dan laksanakanlah dengan penuh ketelitian sehingga tercermin dalam seluruh aktivitas lahir batinmu. Janganlah sampai ada sesuatu yang bersumber darimu mengeruhkan keadilan itu. Sedangkan Kata Syuhadâ' bi al-Qisti mengisyaratkan bahwa persaksian yang ditunaikan itu hendaknya karena Allah, bukan untuk tujuan-tujuan duniawi yang tidak sejalan dengan nilai-nilai Ilahi.

Menurut M. Quraish Shihab bahwa didahulukannya perintah menjadi penegak keadilan adalah dikarenakan tidak sedikit orang yang hanya pandai memerintahkan yang ma'ruf, tapi ketika gilirinnya untuk melaksanakan yang ma'ruf dia lalai. Ayat ini memerintahkan mereka dan semua orang untuk melaksanakan keadilan pada dirinya baru menjadi saksi yang mendukung atau memberatkan orang lain. Di sisi lain, penegakan keadilan atau kesaksian menjadi dasar untuk menampik mudharat yang dapat dijatuhkan.

${ }^{31} \mathrm{Abu}$ Husain Muslim bin al-Hajâj bin Muslim al-Qusyari alNaisâburi, Sahîh Muslim bi Syarh al-Nawawi: Bâb Tahrîm alZhulm, 131-132. Lihat Ahmad bin Hanbal, Musnad Ahmad bin Hanbal, Juz 35 (Beirût: al-Muassasah al-Risâlah, 1999), 332.
Bila demikian, maka menurutnya menjadi wajar penegakan keadilan didahulukan karena menolak kemudharatan yang menimpa pada dirinya. Atau karena penegakan keadilan memerlukan aneka kegiatan yan berbentuk fisik, sedangkan kesaksian hanya dengan ucapan yang demikian. Hal ini tentu saja penegakan keadilan dengan fisik lebih berarti daripada sekedar ucapan. ${ }^{32}$

Cabang asas keadilan adalah prinsip perlakuan yang sama (al-mu'amalah bil mitsl). Perlakuan yang sama tersebut adalah bagian dari prinsip keadilan yang berlaku dalam hubungan dan pergaulan antar manusia, baik pada level individual maupun level kelompok. Sebagaimana sabda Nabi SAW sebagai berikut:

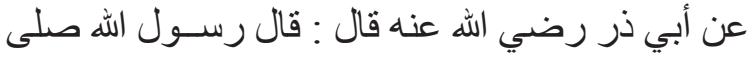

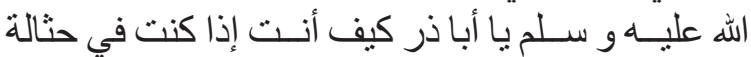

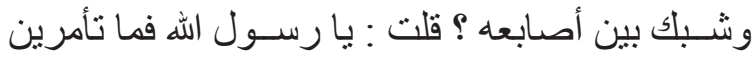

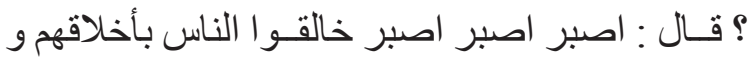
خالفو هم في أعمالهم : اهبر

"Dari Abu Dzar Ra berkata, Rasulullah SAW bersabda: Wahai Abu Dzar bagaimana ketika engkau berada di dekat Hatsalah, apakah ia mengepalkan di antara jari tangannya?. Aku menjawab: Apa yang Engkau perintahkan kepada-ku?. Beliau menjawab: Bersabarlah, bersabarlah, bersabarlah, bergaullah dengan orang-orang sesuai akhlak mereka dan bedakanlah dalam amalan mereka". ${ }^{33}$

Maksud dari hadis tersebut adalah memperlakukan manusia dengan melihat keadaan mereka, baik muda, tua, muslim maupun non muslim. Dalam hal ini Islam menghargai manusia dalam hal menjalin kerukunan antar umat beragama. Tidak saling

\footnotetext{
${ }^{32}$ M. Quraish Shihab, Tafsir Al-Misbah: Pesan, Kesan dan Keserasian al-Qur'an, Jilid 2 (Jakarta: Lentera Hati, 2011), 757758.

${ }^{33}$ Muhammad bin Abdillah Abu Abdillah al-Hâkim al-Naisâburi, Al-Mustadrak 'ala al-Sahîhain, Juz 3 (Beirût: Dâr al-Kutub alIlmiyyah, 1990), 386. Lihat Sulaimân bin Ahmad al-Tabrani, AlMu'jam al-Ausat, Juz 1 (Kairo: Dâr al-Haramain, 1995), 151.
} 
mencaci antara sesama manusia karena samasama merupakan makhluk Allah.

2. Contoh penafsiran dengan metode tahlîli (Analisis)

Penafsiran metode akan terlihat jelas ketika menjelaskan salah satu ayat dari alQur'an, sebagai salah contoh penafsiran pada surat al-Baqarah ayat 3 sebagai berikut:

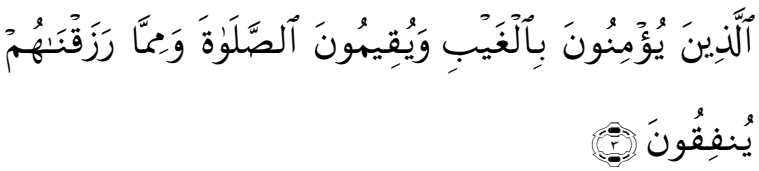

"Yaitu mereka yang beriman kepada yang ghaib, melaksanakan shalat, dan menginfakkan sebagian rezeki yang Kami berikan kepada mereka" (QS. al-Baqarah 2: 3).

Perkara ghaib yang dimaksud adalah jalan Allah, Malaikat, dan lain-lain. Oleh karena itu, barang ghaib tidak akan dapat dicapai oleh kita, maka hanya wajib beriman saja dengan keimanan yang sungguh-sungguh. Kalimat dalam al-Qur'an disebutkan sebanyak 36 kali. Adapun keterangan yang lebih jelas dapat dilihat dalam tafsir ayat surat ke- $6: 59$ dan $72: 27 .{ }^{34}$

Sedangkan kata (الصيلاة) menurut bahasa berarti do'a (permohonan), sedangkan menurut istilah (yang sudah ditetapkan) dalam ilmu fiqh adalah ucapan dan perbuatan yang dimuliakan dengan takbir dan diakhiri dengan salam, dan wujud sembahyang (shalat) ialah berdiri, rukuk, i'tidal, sujud, duduk, dan tahiyat. ${ }^{35}$

Sebelum al-Qur'an semua ahli agama telah mengerjakan shalat, hanya saja mereka belum sempurna shalatnya. Kemudian alQur'an juga datang menerangkan sifat orang mukmin, yaitu orang yang mengerjakan dan mendirikan shalat. Kata إقامـة الصــلاة artinya menjalankan shalat sesuai syarat, rukun,

${ }^{34}$ Lajnah Tafsir PP Muhammadiyah, Tafsir Al-Qoer'an (Djogjakarta: Hoofdbestuur Moehammadiyah Taman Poestaka, 1957), 22. ${ }^{35}$ Ibid., dan adab-adab shalat. Misalnya, suci dari hadas dan najis, menutup aurat, menghadap ke kiblat, khusyu' hatinya ditunjukan dan dibulatkan hanya kepada Allah SWT. Jika direnungkan bahwa cara shalat menurut syari' at Islam adalah sempurna cara shalatnya, karena shalat itu penuh dengan hikmah yang sangat besar, yakni menebalkan iman dan kepercayaan, memperbaiki dan mempertinggi budi serta perbuatan. ${ }^{36}$

Menurut riwayat Ibnu Abbas bahwa yang dimaksud dengan membelanjakan sebagian rezeki adalah zakat, Ibnu Mas'ûd, memberi nafkah kepada kerabat. Imam al-ㅁahâk mengatakan lebih kepada hukumnya, bahwa bersedekah itu adalah sunat. Akan tetapi karena semua sudah ada ayatnya masingmasing, maka kalimat (ينفقـون) di sini tidak dapat dikhususkan, karena kalimat ini bersifat umum. Hanya dalam ayat menyimpulkan bahwa amalan membelanjakan sebagian rezeki yang telah diberikan oleh Allah SWT kepada yang semestinya merupakan suatu perbuatan terpuji. Perbuatan tersebut termasuk sifat orang muttaqîn (orang-orang yang bertakwa), orang mukmin, dan orang yang memperoleh petunjuk al-Qur'an. ${ }^{37}$

\section{Kesimpulan}

Berdasarkan uraian di atas dapat disimpulkan, bahwa Corak Tafsir Muhammadiyah adalah tafsîr bi al-ra' yi, namun corak tafsir bi al-ra' yi yang lebih populer dan dikenal di kalangan Muhammadiyah dengan sebutan tafsîr ijtihâdi (tafsir yang bersifat ijtihad) untuk memahami al-Qur'an, sehingga dalam perkembangan penafsiran Muhammadiyah tidak mengandalkan pendapat semata, tetapi menginterkoneksikan dan mengkorelasikan dengan ayat lain, hadis Nabi, pendapat para sahabat, dan tabi'in. Untuk mengantarkan kepada corak penafsirannya yang memiliki karakteristik al-ra'yi (pemikiran dan ijtihad),

\footnotetext{
${ }^{36}$ Ibid.,

${ }^{37}$ Ibid.,
} 
Muhammadiyah menggunakan dua metode yang digagas oleh para ahli tafsir, yaitu metode maud $\hat{u}^{\prime} i$ (tematis) dan metode tahlîli (analitis). Metode maud $\hat{u}$ ' $i$ diterapkan Muhammadiyah ke dalam karya tafsir yang berjudul "Tafsir Tematik al-Qur'an tentang Hubungan Sosial Antar Umat Beragama”. Sedangkan metode tahlîli diterapkan pada karya tafsir yang berjudul "Tafsir al-Qoer'an. Corak dan dua metode penafsiran yang dikembangkan Muhammadiyah adalah untuk menjawab permasalahan yang terjadi sekarang sehingga al-Qur'an menjadi sâlihun li kulli zamânin wa makânin (sesuai dengan segala waktu dan tempat).

\section{Daftar Kepustakaan}

Abdillah, Abu Muhammad bin Ahmad bin Abi Bakr bin Farh al-Anshâri al-Khazraji. Tafsîr al-Qurtubi. Vol. 1. Kairo: Dâr alKutub al-Mishriyah, 1964.

Abdillah, Muhammad bin Abu Abdillah alHâkim al-Naisâburi. Al-Mustadrak 'ala

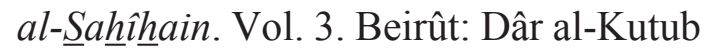
al-Ilmiyyah, 1990.

Abdurrahman, Abdullah bin bin Fadhl bin Bahrâm al-Dârimi. Sunan al-Dârimi. Vol. 1. Riyâdh: Dâr al-Mughni, 2000

Abu, Muhammad Zahrah. Usû́l Fiqh. Kairo: Dâr al-Fikr al-Arabi, 2006.

Ahmad, Sulaimân bin al-Tabrani. Al-Mu'jam alAusat. Vol. 1. Kairo: Dâr al-Haramain, 1995.

Asjmuni Abdurrahman. Manhaj Tarjih Muhammadiyah: Metodologi dan Aplikasi. Yogyakarta: Pustaka Pelajar, 2007.

al-Bukhâri, Muhammad Ismail. S Sahîh $\underline{h}$ al-Bukhâri. Vol. 9. Beirût: Dâr Thûq al-Najâh, 1422. al-Dâruquthni, Ali bin Umar. Sunan al-Dâruqutni. Vol. 1. Beirût: Al-Muassasah al-Risâlah, 2004.
Dayyif, Syauqi, dkk. Al-Mu'jam al-Wasît. Kairo: Maktabah Syurûq al-Dawliyah, 2004.

Departemen Agama RI, Al-Hikmah. Al-Qur'an dan Terjemahnya. Bandung: Diponegoro, 2006.

al-Dzahabi, Muhammad Husain. Al-Tafsir wa al-Mufassirun. Kairo: Maktabah Wahbah, 2000 .

al-Hajaj, Muslim bin Abu Husain al-Qusyairiy al-Naisaburi. $\underline{\text { Sahîh }}$ Muslim, Bâb Bayâni Ajr al-Hâkim. Vol. 5. Riyâd: Bait al-Afkâr al-Dawliyah, 1998.

Hanbal, Ahmad bin. Musnad Ahmad bin $\underline{\text { Hanbal. }}$ Vol. 35. Beirût: al-Muassasah al-Risâlah, 1999.

Kamal, Mustafa Pasha dan Ahmad Adabi Darban. Muhammadiyah Sebagai Gerakan Islam, Yogyakarta: Pustaka SM, 2009.

Lajnah Tafsir PP. Muhammsadiyah. Tafsir AlQoer'an. Djogjakarta: Hoofdbestuur Moehammadiyah Taman Poestaka, 1957.

M. Alfatih Suryadilaga, dkk. Metodologi Ilmu Tafsir. Yogyakarta: Teras, 2005.

M. Quraish Shihab. Membumikan Al-Qur'an: Fungi dan Peran wahyu dalam Kehidupan Masyarakat. Bandung: Mizan, 1999.

Tafsir Al-Misbah: Pesan, Kesan dan Keserasian al-Qur'an. Jakarta: Lentera Hati, 2011.

-------. Wawasan AL-Qur'an: Tafsir Maudhu'i atas Pelbagai Persoalan Umat. Bandung: Mizan, 1998.

Majelis Tarjih dan Pengembangan Pemikiran Islam PP. Muhammadiyah. Tafsir Tematik Al-Qur'an tentang Hubungan Sosial Antarumat Beragama. Yogyakarta: Pustaka SM, 2000.

Muhammad Zaini. "Sumber-sumber Penafsiran al-Qur'an.” Substantia 14, no. 1 (2012): 32. 
Nashruddin Baidan. Metode Penafsiran AlQur'an: Kajian Kritis Terhadap Ayat-ayat yang Beredaksi Mirip. Jakarta: Pustaka Pelajar, 2011.

al-Qattân, Mana'. Mabâhits fi 'Ulûm al-Qur'ân. Riyâd: Dâr al-Su'ûdiyah, t.t.

al-Râzi, Muhammad bin Abi Bakar bin Abdul Qâdir. Mukhtâr al-Sihhâh $\underline{h}$. Kairo: Dâr alHadîts, 2008.

al-Sâbûni, Muhammad Ali. Al-Tibyân fi 'Ulûm
al-Qur'ân. Jakarta: Dâr al-Kutub alIslâmiyah, 2003.

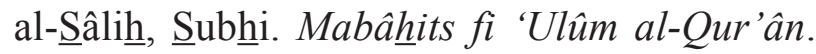
Beirût: Dâr al-'Ilmu al-Malâyîn, 1977.

Samsul Nizar. Memperbincangkan Dinamika Intelektual dan Pemikiran HAMKA tentang Pendidikan Islam. Jakarta: Kencana, 2008.

al-Zarqâni, Muhammad Abd al-'Ażîm. Manâhi al-'Irfân fi 'Ulûm al-Qur'ân. Beirût: Dâr al-Kitâb al-'Arabi, 1995. 